\title{
New data on Malayometastrongylus diardinematus (Gibbons and Krishnasamy, 1986) (Metastrongyloidea: Angiostrongylidae) a lungworm occurring in Rattus tanezumi (Temminck, 1844) from South-East Asia
}

\author{
M. VECIANA ${ }^{1}$, K. CHAISIRI ${ }^{2}$, O. PHUPHISUT ${ }^{2}$, S. MORAND $^{3,4}$, A. RIBAS $^{1,5^{*}}$
}

\begin{abstract}
${ }^{1}$ Laboratory of Parasitology, Faculty of Pharmacy, University of Barcelona, Avda. Diagonal s/n, 08028 Barcelona, Spain, E-mail: aribas@ub.edu; ${ }^{2}$ Department of Helminthology, Faculty of Tropical Medicine, Mahidol University, Bangkok 10400, Thailand; ${ }^{3}$ Institut des Sciences de l'Evolution, CNRS-IRD-UM2, CC065, Université de Montpellier 2, 34095 Montpellier, France; ${ }^{4}$ Centre d'Infectiologie Christophe Mérieux du Laos, Vientiane, Lao PDR; ${ }^{5}$ Biodiversity Research Group, Faculty of Science, Udon Thani Rajabhat University, Udon Thani 41000, Thailand
\end{abstract}

\begin{abstract}
Summary
A survey of rodents from Luang Prabang Province (Lao PDR) in February 2010 and May 2012 allowed examining lungs of 95 rodents belonging to 7 different genera (Bandicota, Berylmys, Cannomys, Leopoldamys, Maxomys, Mus, Rattus). The helminth Malayometastrongylus diardinematus (Nematoda: Metastrongyloidea) was identified in Rattus tanezumi living in close contact with humans, being the first report after its original description in $R$. tanezumi from Malaysia. A molecular study using mitochondrial gene cytochrome $c$ oxidase subunit I (COI) of $M$. diardinematus placed the genus Malayometastrongylus in a separate clade in comparison with Angiostrongylus cantonensis (subgenus Parastrongylus) and other representatives of the genus, both present in rodents of South East Asia.
\end{abstract}

Keywords: Metastrongyloidea; genes; Rodentia; Laos

\section{Introduction}

Malayometastrongylus diardinematus (Gibbons \& Krishnasamy, 1986) was described as a new genus of nematode from lungs of the Asian house rat Rattus tanezumi Temminck, 1844 (described originally as Rattus rattus diardii) in Malaysia. The original description of $M$. diardinematus lacks of information concerning locality, number of hosts studied and if other rodent species were examined for the presence of this lungworm. This nematode has never been reported afterwards despite the Asian house rat shows a wide distribution (Aplin et al., 2003).

Other four angiostrongylids have been reported in rodents from South-East Asia (SEA): Angiostrongylus cantonensis (subgenus Parastrongylus) (Chen, 1935), Angiostrongylus malaysiensis (subgenus Parastrongylus) (Bhaibulaya \& Cross, 1971), Angiostrongylus siamensis (subgenus Parastrongylus) (Ohbayashi et al., 1979) and Thaistrongylus harinasutai (Ohbayashi et al., 1979).
Angiostrongylus cantonensis (subgenus Parastrongylus) is recognized as a zoonotic helminth that has caused hundreds of human angiostrongyliasis worldwide (Wang et al., 2012). This nematode has been reported in central Thailand (Bangkok-Thonburi near the mouth of the Chao Phraya River); North-East (Nakornrajsrima, Ubonratchatani and Udornratchatani); North (Chiang Mai, Sukothai and Nakhon Sawan); West (Kanchanaburi and small villages up the two forks of the Khwae River); South-East (Trat, Chantaburi and Rayong) and South Peninsula (Narathiwat, Yala, Songkhla, Trang, Nakhon Si Thamarat, Krabi, Ranong, Chumpon and Prachuap Khiri Khan) (Crook et al., 1968) from rodents as Bandicota bengalensis Gray, 1835, Bandicota indica (Bechstein, 1800), Rattus exulans (Peale, 1848), Rattus norvegicus (Berkenhout, 1769), Rattus rattus (Linnaeus, 1758) and Rattus sp. It was also reported from North-East Thailand in $R$. norvegicus and B. indica (Pipitgool et al., 1997) and North Thailand (Chiang Mai) in $R$. norvegicus and $R$. rattus (Namue \& Wongsawad, 1997). In other countries as Philippines in $R$. tanezumi (Antolin et al., 2006) and Rattus rattus mindanesis (syn. Rattus rattus) (Fedorko, 1999); in Malaysia in Rattus argentiventer (Robinson \& Kloss, 1916), Rattus tiomanicus (Miller, 1900) (syn. Rattus jalorensis) (Singh \& Cheong, 1971) and additionally in Leopoldamys sabanus (Thomas, 1887) (syn. Rattus sabanus) (Liat et al., 1975), also in Rattus exulans concolor (syn. Rattus exulans) and Rattus rattus diardii (syn. Rattus tanezumi) (Schacher \& Cheong, 1960); and in Indonesia (Java Island) from rodents as $R$. tanezumi (syn. R. r. diardii) and Maxomys bartelsii (Jentink, 1910) (syn. Rattus bartelsii) (Wiroreno, 1978). The presence of $A$. cantonensis has not been reported in rodents of other countries of SEA.

Angiostrongylus malaysiensis (subgenus Parastrongylus) has been reported in Malaysia from R. tanezumi (syn. $R$. $r$. diardii) (Gibbons \& Krishnasamy, 1986; Leong et al., 
1979), $R$. norvegicus and $R$. rattus (Mohd Zain et al., 2012), Rattus jalorensis (syn. Rattus tiomanicus) (Bhaibulaya \& Cross, 1971), R. tiomanicus (Krishnasamy et al., 1980), and in Rattus spp. (R. tiomanicus, $R$. r. diardii, $R$. argentiventer, $R$. norvegicus) (Nur Syazana et al., 2013) in central and western regions of Thailand in $R$. tiomanicus (syn. R. jalorensis) (Bhaibulaya \& Techasoponmani, 1972) and in Indonesia in B. indica, Niviventer lepturus (Jentink, 1879) (syn. R. lepturus), R. tanezumi (syn. R. r. diardii), $R$. exulans, $R$. norvegicus and in $R$. tiomanicus (syn. $R$. jalorensis) (Krishnasamy et al., 1980).

Angiostrongylus siamensis (subgenus Parastrongylus) was reported in Thailand from L. sabanus (Ohbayashi et al., 1979), Berylmys berdmorei (Blyth, 1851), R. rattus and Maxomys surifer (Miller, 1900) (syn. Rattus surifer) (Kamiya et al., 1980) and in Bandicota savilei Thomas, 1916 and B. indica (Ohbayashi et al., 1983).

Finally, T. harinasutai was recovered from B. berdmorei in Thailand and identified by comparison with the original materials of description (Gibbons \& Krishnasamy, 1986), and additional morphological characters were provided. In conclusion, previous studies on angiostrongylids of rodents from SEA, except for A. cantonensis are limited to few studies on Indonesia, Malaysia and Thailand.

The phylogenetic position of some angiostrongylids were studied using cytochrome $c$ oxidase subunit I (COI) (A. cantonensis and A. malaysiensis) (Eamsobhana et al., 2010) and with the complete internal transcribed spacer 2 (ITS-2) and a fragment of the small subunit ribosomal RNA(SSU rRNA) nucleotide sequences (A. cantonensis) (Foronda et al., 2010). Excluding A. cantonensis and $A$. malaysiensis, genetic information is lacking on the other species of angiostrongylids occurring on rodents of SEA.

In the framework of CERoPath and BiodivHealthSEA projects, we report and provide new data: metrical, molecular and biogeographical on the angiostrongylid $M$. diardinematus found in $R$. tanezumi associated to human habitats in Lao PDR.

\section{Material and methods}

\section{Helminth collection}

A total of 95 rodents: B. indica $(\mathrm{n}=13) ; B$. berdmorei $(\mathrm{n}=1)$; Cannomys badius (Hodgson, 1841) $(\mathrm{n}=7)$; Leopoldamys edwardsi (Thomas, 1882) $(\mathrm{n}=4)$; Leopoldamys neilli Marshall, $1976(\mathrm{n}=2) ;$ M. surifer $(\mathrm{n}=2)$; Mus cokii Ryley, $1914(\mathrm{n}=3)$ and $R$. tanezumi $(\mathrm{n}=63)$ captured from Luang Prabang Province (Lao PDR) in Xiang Gneun district $\left(19^{\circ} 36^{\prime} 44^{\prime} ' \mathrm{~N} ; 102^{\circ} 2^{\prime} 41^{\prime}\right.$ ' $\left.\mathrm{E}\right)$ in 2010 and from the village of Lak Sip (19 $50^{\prime} 55^{\prime}{ }^{\prime} \mathrm{N} ; 102^{\circ} 10^{\prime} 4^{\prime}$ 'E) in 2012, were dissected in order to examine its lungs for helminths. Rodents were euthanized and dissected following protocols that maximize animal care, health and safety of field parasitologists and generation of quality data (Herbreteau et al., 2011) (see http://www.ceropath.org/research/protocols). All rodents were identified by morphology following the nomenclature and classification in (Aplin et al., 2003; Marshall, 1988; Pagès et al., 2010). For the problematic species, a molecular identification by using species specific primers and/or barcoding assignments were applied (Galan et al., 2012), details available in Barcoding Tool/RodentSEA section of the CERoPath web site: http://www.ceropath.org.

Nematodes were isolated from lung tissues, transferred to $70 \%$ alcohol and examined in the Laboratory of Parasitology of the Faculty of Pharmacy (University of Barcelona, Spain). For morphological characterization, helminths were mounted in Amman lactophenol. Measurements are in millimetres and compared to measurements of original description by Gibbons \& Krishnasamy (1986). To complete the molecular study we included Parastrongylus dujardini (Drozdz \& Doby, 1970) from the rodents Apodemus sp. and Myodes glareolus (Schreber, 1780) captured in Pyrenees Mountains (France) $\left(42^{\circ} 29^{\prime} 47.76^{\prime \prime} \mathrm{N} ; 2^{\circ} 21^{\prime} 4.68^{\prime \prime} \mathrm{E}\right)$ and $A$. cantonensis (subgenus Parastrongylus) from rodents captured in Thailand: $R$. tanezumi (captured in Chiangrai $\left(19^{\circ} 50^{\prime} 38.11^{\prime \prime} \mathrm{N} ; 99^{\circ} 57^{\prime}\right.$ 55.14"E) and Ranong (10²8'32.88"N;98 48'33.96"E)) and B. indica (captured in Chiangrai $\left(19^{\circ} 50^{\prime} 38.11^{\prime \prime} \mathrm{N} ; 99^{\circ} 57^{\prime}\right.$ 55.14"E)).

\section{DNA extraction}

Genomic DNA of each worm (P. dujardini, A. cantonensis (subgenus Parastrongylus) and $M$. diardinematus) was extracted using tissue Genomic DNA Mini Kits (FavorPrep $^{\mathrm{TM}}$, Taiwan), according to the manufacturer's protocol.

\section{PCR amplification and DNA sequencing}

The DNA amplification by Polymerase Chain Reaction (PCR) was conducted with primers designed from COI sequences of $A$. cantonensis (subgenus Parastrongylus) (GenBank accession number GQ398121), as Ac-COI Forward 5'GTTCTAATCATAAGGATATTG3' and Ac-COI Reverse 5'CAAACAAACAAACTCATATG3'. PCR amplicons were approximately $500 \mathrm{bp}$ in length. $50 \mu \mathrm{L}$ of each PCR reaction was composed of the 1xKAPA TaqReadyMix DNA Polymerase (1U KAPA Taq Polymerase, $1.5 \mathrm{mM} \mathrm{MgCl} 2$ and KAPA Taq Polymerase Buffer), $0.25 \mu \mathrm{M}$ of each primer, and $1 \mu \mathrm{L}$ of DNA template. Amplification conditions were initially heated at $94{ }^{\circ} \mathrm{C}$ for 3 min, followed by 34 amplification cycles, consisting of denaturation at $95{ }^{\circ} \mathrm{C}$ for $30 \mathrm{sec}$, annealing at $53{ }^{\circ} \mathrm{C}$ for 30 sec and elongation $72{ }^{\circ} \mathrm{C}$ for $1 \mathrm{~min}$ and final extension at $72{ }^{\circ} \mathrm{C}$ for $5 \mathrm{~min}$. PCR products were run into $1.0 \%$ agarose gel and visualized on UV-transilluminator. Each PCR amplicons was sequenced using the 2 amplification primers on an ABI's 3730XL DNA Analyzers and BigDye Terminator at AITBIOTECH Pte Ltd (Singapore).

\section{COI sequences from GenBank}

COI sequences from Angiostrongylus vasorum (Baillet, 1866), A. cantonensis (subgenus Parastrongylus), Parelaphostrongylus tenuis Dougherty, 1945, Metastrongylus pudendotectus (Wostokow, 1905), Metastrongylus salmi (Gedoelst, 1823) and Schistosoma mekongi Voge et al., 1978 (used as an outgroup) were obtained from the 


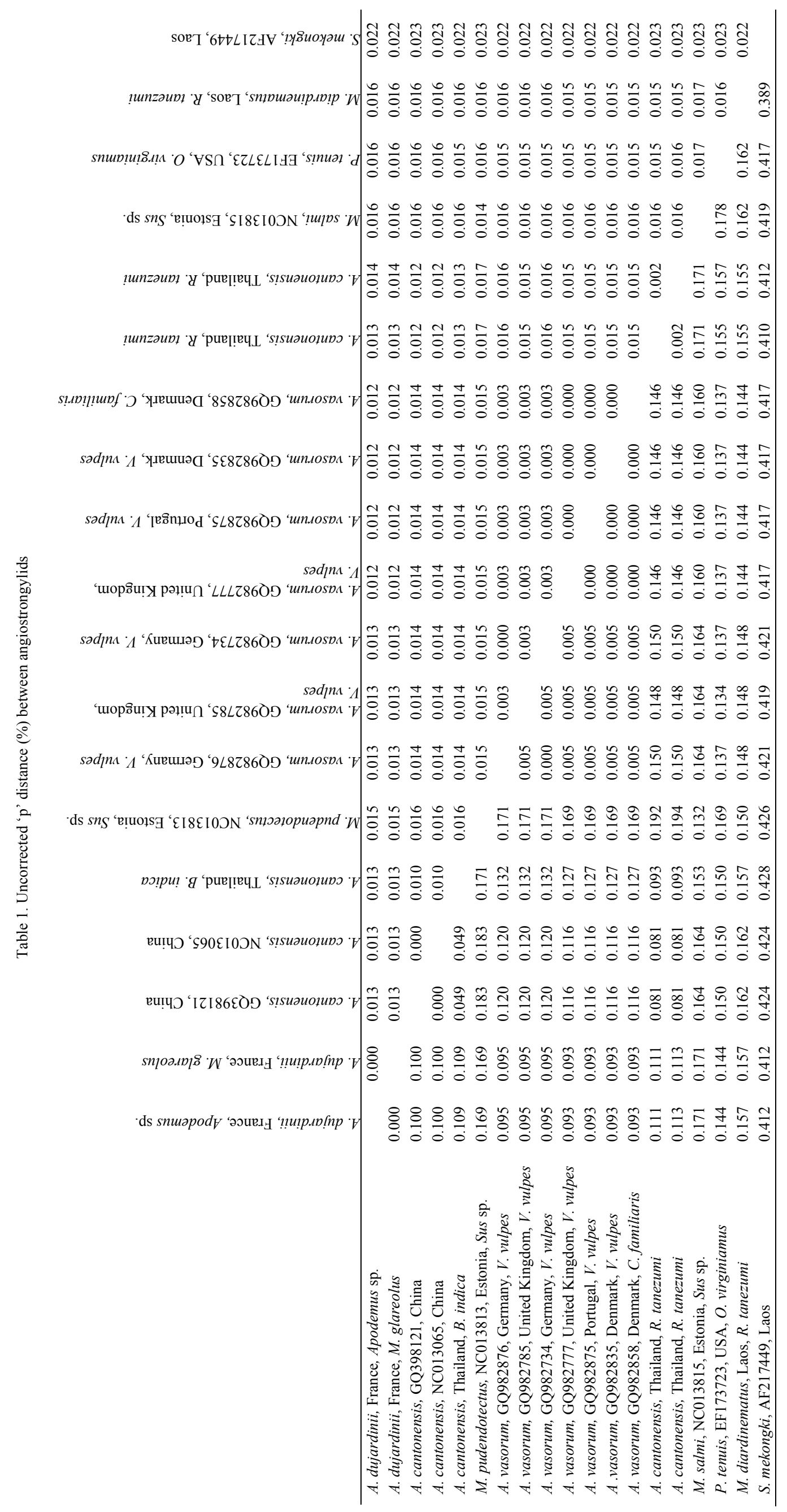


GenBank as follows: A. vasorum GQ982777, GQ982875, GQ982835, GQ982858, GQ982785, GQ982876, GQ982734; A. cantonensis (subgenus Parastrongylus) GQ398121, NC013065; P. tenuis EF173723; M. pudendotectus NC013 813; M. salmi NC013815; and S. mekongi AF217449.

Sequence alignment and phylogenetic analysis

The electropherogram of each sequence was examined for sequence accuracy by BioEdit program version 7.0 (Hall, 1999). The DNA sequences of COI were aligned by CLUSTAL X (Thompson, 1997). All gap sites in the sequences were removed from the alignment. Phylogram was constructed from COI sequences by neighbour-joining (NJ) method by estimating 1000 replications with $p$-distance in MEGA 5 (Tamura et al., 2011).

\section{Results and discussion}

Measurements of worms: oesophagus length $0.277-0.307$ (0.288), $\mathrm{n}=3$; right spicule $0.195-0.198(0.196), \mathrm{n}=2$; left spicule $0.195-0.204(0.200), \mathrm{n}=2$; distance from anus to tip of tail $0.064-0.072(0.068), \mathrm{n}=2$; distance from vulva to tip of tail $0.193-0.250(0.214), n=3$; eggs (length $\mathrm{x}$ width) $0.050-0.059(0.056) \times 0.034-0.040$ (0.037), $\mathrm{n}=52$; width at the base of oesophagus 0.035 0.039 (0.037), $\mathrm{n}=2$ :, and oesophagus maximum width $0.060-0.069(0.063), \mathrm{n}=3$.
Helminths were found in lungs of $9 R$. tanezumi captured in February 2010 from Xiang Gneun district, being all other captured rodents (86) negative for this worm. The worm fragility and as are imbricate in lungs do not allow counting the number of individuals in each host, additionally the presence of male nematodes was scarce.

Measures of worms are in accordance with original description (Gibbons \& Krishnasamy, 1986) of M. diardinematus: oesophagus length $0.266-0.353, \mathrm{n}=8$; spicules $0.171-0.240, \mathrm{n}=13 ; 0.163-0.225, \mathrm{n}=13$; distance from anus to tip of tail $0.042-0.089, \mathrm{n}=4$; distance from vulva to tip of tail $0.228-0.318, \mathrm{n}=4$; eggs (length $\mathrm{x}$ width) $0.057-0.068 \times 0.034-0.046, \mathrm{n}=$ unknown.

This is the first report of $M$. diardinematus after the original description in $R$. tanezumi from Malaysia, so consequently this nematode has a wider distribution than previously expected as has been found in two points separated more than $2000 \mathrm{~km}$ (Malaysia and Lao PDR). M. diardinematus has a prevalence of $23.08 \%$ in 2010 and was absent in 2012 samples. We suggest the lack of reports in SEA is related to the small size and fragility of these worms if we compare with A. cantonensis (subgenus Parastrongylus) and A. malaysiensis (subgenus Parastrongylus), being its zoonotic potential known (Wang et al., 2012).

A molecular study using mitochondrial gene cytochrome $c$ oxidase subunit I (COI) of $M$. diardinematus confirms the validity of the genus Malayometastrongylus differing from

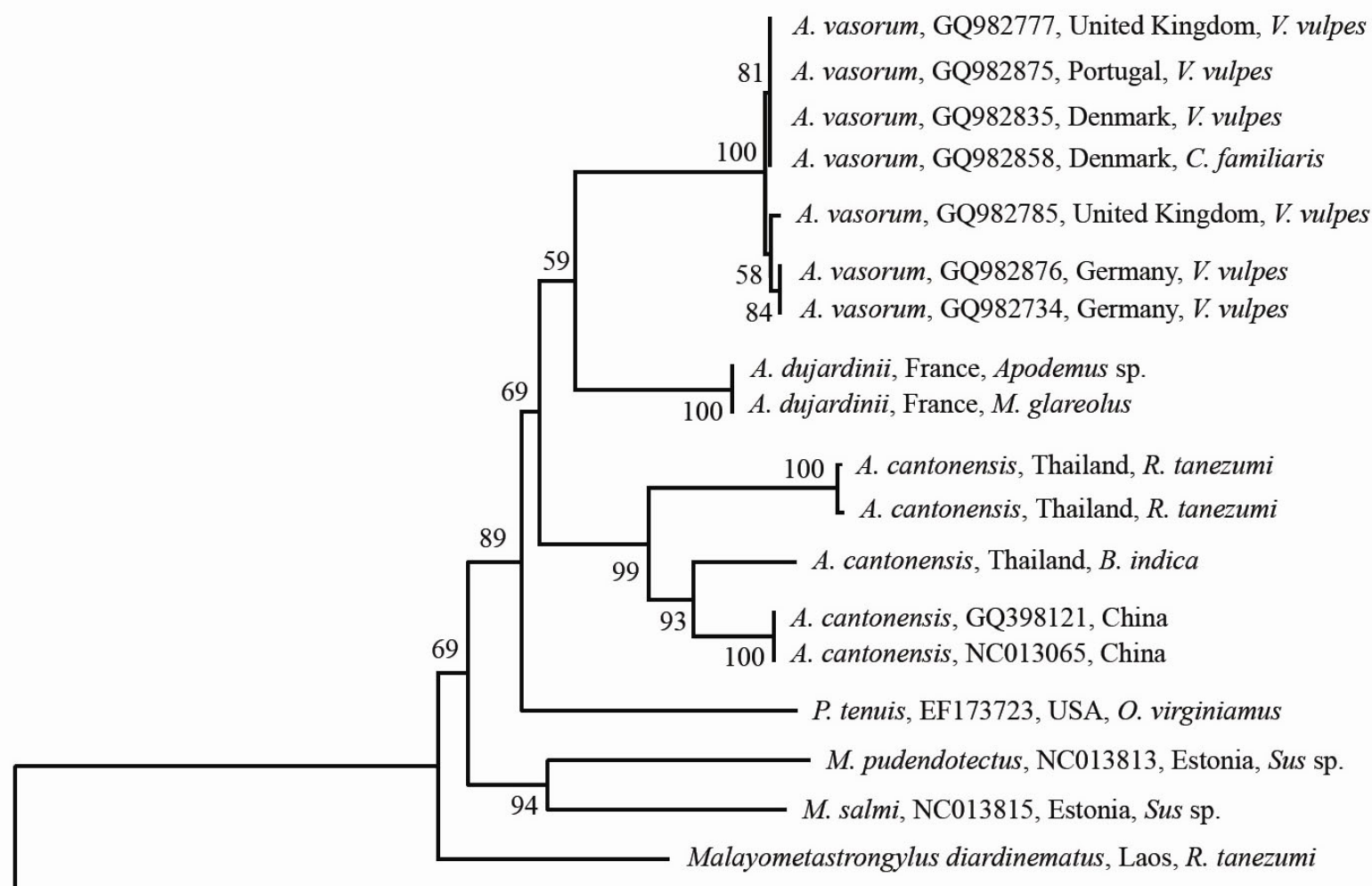

Schistosoma mekongi, AF217449, Laos

Fig. 1. Phylogeny tree using partial COI gene sequences by neighbour-joining (NJ) method 
subgenus Angiostrongylus and Parastrongylus (Fig. 1). Our molecular results show that the phylogenetic analysis does not support the differentiation of the subgenus Angiostrongylus and Parastrongylus based in the mitochondrial gene COI as has also been concluded in previous studies (Eamsobhana et al., 2010). Molecular analysis shows that Malayometastrongylus is placed in a separate clade distant of Angiostrongylus and Parastrongylus (Figure 1; Table 1). Future research should be addressed in solve the phylogenetic position of the other four angiostrongylid reported in SEA rodents to a better understanding of this group of nematodes. Additionally, the limited number of available sequences of COI gene in angiostrongylids despite its high diversity of genera reveals further to research for better understanding of phylogenetic relationships.

\section{Acknowledgements}

This study was supported by French ANR 11 CPEL 002, project BiodivHealthSEA, Local impacts and perceptions of global changes: Biodiversity, health and zoonoses in Southeast Asia (www.biodivhealthsea.org) and the French ANR Biodiversity ANR 07 BDIV 012, project CERoPath, Community Ecology of Rodents and their Pathogens in a changing environment (www.ceropath.org). A. Ribas was partially supported by 2014-SGR-1241 from the Catalan Government.

\section{References}

Antolin, M. M., Joshi, R. C., Sebastian, L. S., Marquez, L. V, Duque, U. G., Domingo, C. J. (2006): Endo- and ectoparasites of the Philippine rice field rat, Rattus tanezumi Temminck, on PhilRice farms. Int. Rice Res. Notes, 31(1): 26 - 27. DOI: 10.3860/irrn.v31i1.1188 Aplin, K. P., Brown, P. R., JACOB, J., Krebs, C., Singleton, G. R. (2003): Field methods for rodent studies in Asia and the Indo-Pacific. Canberra: ACIAR Monograph (Vol. 100). Canberra: ACIAR Monograph.

Bhaibulaya, M., Cross, J. H. (1971): Angiostrongylus malaysiensis (Nematoda: Metastrongylidae), a new species of rat lung-worm from Malaysia. Southeast Asian J. Trop. Med. Public Health, 2(4): 527 - 533.

Bhaibulaya, M., Techasoponmani, V. (1972): Mixed infections of Angiostrongylus spp. in rats in Bangkok. Southeast Asian J. Trop. Med. Public Health, 3(3): 451

Crook, J. R., Fulton, S. E., Supanwong, K. (1968): Ecological studies on the intermediate and definitive hosts of Angiostrongylus cantonensis (Chen, 1935) in Thailand. Ann. Trop. Med. Parasitol., 62(1): 27 - 44

Eamsobhana, P., Lim, P. E., Solano, G., Zhang, H., GAN, H., YONG, H. S. (2010): Molecular differentiation of Angiostrongylus taxa (Nematoda: Angiostrongylidae) by citochrome c oxidase subunit I (COI) gene sequences. Acta Trop., 116(2): 152 - 156. DOI: 10.1016/j.actatropica.2010. 07.005

FEDORKO, J. M. (1999): Schistosoma japonicum in the black rat, Rattus rattus mindanensis, from Leyte, Philippi- nes in relation to Oncomelania snail colonies with reference to other endoparasites. Southeast Asian J. Trop. Med. Public Health, 30(2): 343 - 349

ForondA, P., LÓPEZ-GONZÁlez, M., MiQuel, J., TORRES, J., Segovia, M., ABreu-Acosta, N., Foronda, P., LópezGonzález, M., Miquel, J., Torres, J., Segovia, M., Abreu-Acosta, N., Casanova, J. C., Valladares, B., Mas-Coma, S., BARgues, M. D., Feliu, C. (2010): Finding of Parastrongylus cantonensis (Chen, 1935) in Rattus rattus in Tenerife, Canary Islands (Spain). Acta Trop., 114(2): 123 - 127. DOI: 10.1016/j.actatropica.2010.02.004 Galan, M., PAgÉs, M., Cosson, J. F. (2012): Next-generation sequencing for rodent barcoding: species identification from fresh, degraded and environmental samples. PLoS ONE, 7(11): e4837. DOI: 10.1371/journal.pone.0048374

GiBBOns, L. M., KrishnASAMY, M. (1986): Malayometastrongylus diardinematus n. g., n. sp. (Metastrongyloidea: Angiostrongylidae) from Rattus rattus diardii in Malaysia and a redescription of Thaistrongylus harinasutai Ohbayashi, Kamiya \& Bhaibulaya, 1979. Syst. Parasitol., 8(2): $107-115$

HALL, T. A. (1999): BioEdit: a user friendly biological sequence alignment editor and analysis program for Windows 95/98/NT. Nucleic Acids Symp. Ser., 41: 95 - 98

Herbreteau, V., JitTapalapong, S., RERKAMnUAYChOKe, W., Chaval, Y., Cosson, J. F., Morand, S. (2011): Protocols for Field and Laboratory Rodent Studies (Vol. 1, p. 46). Thailand: Kasetsart University Press.

KamiYa, M., OKU, Y., Katakura, K., KamiYA, H., Ohbayashi, M., Abe, H., Suzuki, H., Bhaibulaya, M. (1980): Report in the prevalence and experimental infections of Angiostrongylus siamensis Ohbayashi, Kamiya et Bhaibulaya, 1979, parasitic in the mesenteric arteries of rodents in Thailand. Jpn. J. Vet. Res., 28(4): $114-121$

Krishnasamy, M., Singh, K. I., AmbU, S., RamachanDRAN, P. (1980): Seasonal prevalence of the helminth fauna of the wood rat Rattus tiomanicus (Miller) in West Malaysia. Folia Parasitol., 27(3): 231 - 235

LeONG, T. S., LiAT, L. B., YAP, L. F., KRIShNASAMY, M. (1979): Parasite fauna of the house rat Rattus rattus diardii in Kuala Lumpur and nearby villages. Southeast Asian J. Trop. Med. Public Health, 10(1): 122 - 126

LiAT, L. B., WAH, M. J., Singh, M., Ho, B. C., HiAn, Y. E. (1975): Distribution and ecological consideration of Breinlia booliati infecting wild rodents in Malaysia. Southeast Asian J. Trop. Med. Public Health, 6(2): 241-246

MARSHALl, J. T. (1988): Family Muridae: Rats and mice. In B. LeKagul \& J. A. MC NeEly (Eds), Mammals of Thailand (pp. 397 - 487). Bangkok: Association for the Conservation of Wildlife.

Mohd Zain, S. N., BehnKe, J. M., LeWIS, J. W. (2012): Helminth communities from two urban rat populations in Kuala Lumpur, Malaysia. Parasit. Vectors, 5: 47. DOI: 10.1186/1756-3305-5-47

NAmue, C., WongSaWAd, C. (1997): A survey of helminth infection in rats (Rattus spp) from Chiang Mai Moat. Southeast Asian J. Trop. Med. Public Health, 28(Suppl 1): $179-183$ 
Nur Syazana, M. T., Mohd Zain, S. N., Jeffery, J. (2013): Biodiversity and macroparasitic distribution of the wild rat population of Carey Island, Klang. Trop. Biomed., 30(2): $1-12$

OHBAyAshi, M., KamiYa, M., Bhaibulaya, M. (1979): Studies on the parasite fauna of Thailand I. Two new metastrongylid nematodes, Angiostrongylus siamensis sp. $\mathrm{n}$. and Thaistrongylus harinasutai gen. et sp. n. (Metastrongyloidea; Angiostrongylidae) from wild rats. Jpn. J. Vet. Res., 27(1-2): $5-10$

Ohbayashi, M., Mach Ida, M., KamiYa, H., OKU, Y., ABE, H., KLONGKAMNUANKARN, K. (1983): Incidende of Angiostrongylus siamensis in small mammals at Nakorn Nayok, Thailand. Jpn. J. Vet. Res., 31(1): 49 - 50

Pagès, M., Chaval, Y., Herbreteau, V., WaengSothorn, S., Cosson, J. F., Hugot, J. P., Morand, S., MichauX, J. (2010): Revisiting the taxonomy of the Rattini tribe: a phylogeny-based delimitation of species boundaries. BMC Evolutionary Biology, 184: DOI: 10.1186/1471-2148-10-184

Pipitgool, V., Sithithaworn, P., Pongmuttasaya, P., HINZ, E. (1997): Angiostrongylus infections in rats and snails in northeast Thailand. Southeast Asian J. Trop. Med. Public Health, 28(Suppl 1): 190 - 193
Schacher, J., CheOng, C. (1960): Malaysian parasites. XLVII. Nematode parasites of three common house rat species in Malaya, with notes on Rictularia tani Hoeppli, 1929. In Studies from the Institute for Medical Research, Federated Malay States (Vol. 29, pp. 209 - 216)

Singh, M., CheONG, C. (1971): On a collection of nematode parasites from Malayan rats. Southeast Asian J. Trop. Med. Public Health, 2(4): 516 - 522.

Tamura, K., Peterson, D., Peterson, N., Stecher, G., NEI, M., KUMAR, S. (2011): MEGA5: molecular evolutionary genetics analysis using maximum likelihood, evolutionary distance, and maximum parsimony methods. Mol. Biol. Evol., 28(10): 2731 - 2739. DOI: 10.1093/molbev/ msr121

ThOMPson, J. (1997): The CLUSTAL_X windows interface: flexible strategies for multiple sequence alignment aided by quality analysis tools. Nucleic Acids Res., 25(24): 4876 - 4882. DOI: $10.1093 / \mathrm{nar} / 25.24 .4876$

WANG, Q. P., WU, Z. D., WEI, J., OWEN, R. L., LUN, Z. R. (2012): Human Angiostrongylus cantonensis: an update. Eur. J. Clin. Microbiol. Infect. Dis., 31(4): 389 - 395. DOI: $10.1007 / \mathrm{s} 10096-011-1328-5$

WIRORENO, W. (1978): Nematode parasites of rats in West Java, Indonesia. Southeast Asian J. Trop. Med. Public Health, 9(4): 520 - 525

ACCEPTED August 24, 2014 